\title{
Naar een betere opbrengst van de deskundigeninbreng
}

\author{
Verslag van de voorjaarsvergadering 2017 van de Nederlandse Vereniging \\ voor Procesrecht
}

Mr.J.J. Dammingh en mr. L.M. van den Berg*

\begin{abstract}
Algemeen
De voorjaarsvergadering van 2017 van de Nederlandse Vereniging voor Procesrecht (hierna: NVvP), die plaatsvond op 16 juni 2017, droeg de titel 'Naar een betere opbrengst van de deskundigeninbreng.

De voorzitter, prof. mr. C.J.M. Klaassen, heeft bij wijze van inleiding (de keuze voor) het thema van deze vergadering en de achtergronden ervan toegelicht. Het is de taak van de rechter om in een procedure recht te spreken op basis van de feiten zoals die (tussen partijen) zijn komen vast te staan. Met het oog op de feitengaring kan het soms wenselijk c.q. noodzakelijk zijn dat de rechter zich door een deskundige laat voorlichten. Art. 194 t/m 200 Rv geven regels voor het deskundigenbericht.
\end{abstract}

In veel procedures is een deskundigenbericht niet aan de orde. Maar in de procedures waarin wel een deskundigenbericht wordt ingewonnen, speelt (de uitkomst van) dat bericht vaak een cruciale rol. Een deskundigenbericht is nuttig met het oog op de vaststelling van feiten die zonder deskundigheid niet zijn vast te stellen. Hierbij kan ook aan het bepalen van (de omvang van) schade worden gedacht. De praktijk leert evenwel dat aan het deskundigenbericht de nodige haken en ogen zitten. Zo is het aan de '(eigen) wijsheid' van de rechter overgelaten om te beslissen of een deskundigenbericht zal worden gelast. Uit art. 194 lid $1 \mathrm{Rv}$ volgt immers dat de rechter een deskundige kan benoemen. Hij is daartoe dus niet verplicht (ook al zouden beide partijen dat wensen). En als de rechter - op verzoek van partijen of ambtshalve - een deskundige wil inschakelen, dan blijkt het lang niet altijd eenvoudig te zijn om een goede deskundige te vinden. Verder staat niet op voorhand vast dat de deskundige - zodra deze is gevonden - een bericht zal uitbrengen dat voor de rechter bruikbaar zal zijn. Het is dus de vraag hoe de deskundige door de rechter (en partijen) zo kan worden 'voorgesorteerd' dat zijn onderzoeks-

\footnotetext{
Mr. J.J. Dammingh is universitair hoofddocent burgerlijk (proces)recht aan de Radboud Universiteit Nijmegen en tevens advocaat te Nijmegen. Mr. L.M. van den Berg is stafjurist in de Rechtbank Gelderland en tevens verbonden aan de sectie burgerlijk (proces)recht van de Radboud Universiteit Nijmegen.
}

bevindingen daadwerkelijk zullen (kunnen) bijdragen aan de juridische beoordeling van het geschil. En op welke wijze kunnen de neutraliteit en deskundigheid van de deskundige en - meer in het algemeen - de zorgvuldigheid van de deskundigenprocedure worden gewaarborgd? Deze aspecten waren voor het bestuur van de NVvP aanleiding om tijdens deze vergadering bij het deskundigenbericht stil te staan.

Stellingen:

\section{Inleiding mr. J.F. Aalders ${ }^{1}$}

1. Het benoemen van een deskundige door de rechter zou ultimum remedium moeten zijn.

2. Advocaten moeten hun natuurlijke neiging onderdrukken om bezwaar te maken tegen de deskundige van de wederpartij.

3. Voor een goed deskundigenbericht is enige basiskennis van het juridisch besluitvormingsproces een pre.

\section{Inleiding}

Aalders merkt op dat haar is verzocht om een inleiding te verzorgen over het deskundigenbericht vanuit de invalshoek van de rechter in de civiele (proces)praktijk. Onder rechters is het deskundigenbericht niet populair, omdat het - in de beleving van de meeste rechters - in veel gevallen (te) tijdrovend en (te) kostbaar is. Bovendien gebeurt het meer dan eens dat het door de deskundige uitgebrachte rapport niet de inhoud heeft waarop vooraf was gerekend, waardoor het voor de beslechting van het geschil niet of minder goed bruikbaar is. Tegen die achtergrond werpt Aalders de vraag op of een deskundigenbericht in een civiele procedure wel in alle gevallen nuttig c.q. nodig is (hier ziet ook de eerste stelling van Aalders op). $\mathrm{Zij}$ is van mening dat deze vraag ontkennend moet worden beantwoord, enerzijds omdat de rechter in de praktijk op nogal wat problemen stuit bij het inwinnen van een deskundigenbericht en anderzijds omdat wellicht een (reëel) alternatief voorhanden is. Alvorens nader op dat alternatief in te gaan, geeft Aalders eerst een indruk van de vele haken en ogen die in de praktijk aan het deskundigenbericht zitten.

1. Raadsheer in het gerechtshof te Amsterdam. 
Hoe wordt het deskundigenbericht in een civiele procedure ingepast? Doorgaans wijst de rechter eerst een tussenvonnis (in hoger beroep een arrest) waarin hij melding makt van het voornemen om - op de voet van art. 194 van het Wetboek van Burgerlijke Rechtsvordering $(\mathrm{Rv})$ - een deskundige in te schakelen. In dit tussenvonnis vermeldt de rechter tevens de vragen die hij voornemens is aan de deskundige te stellen en biedt hij partijen gelegenheid om zich - bij akte - over de persoon van de te benoemen deskundige uit te laten, en eventueel ook over aan de deskundige voor te leggen aanvullende vragen. Vervolgens nemen partijen elk een akte met daarin voorstellen en soms ook bezwaren. Als dan - na een vaak moeizame zoektocht - een deskundige is gevonden, dient een voorschot met het oog op diens kosten te worden vastgesteld (over de hoogte waarvan partijen zich ook nog mogen uitlaten). De deskundige vangt zijn onderzoek aan zodra het voorschot (door partijen) is gestort. Hij verwoordt de bevindingen van zijn onderzoek in een concept-rapport, dat voor een reactie aan partijen wordt voorgelegd, waarna het definitieve rapport (aan de rechter) wordt uitgebracht. Partijen mogen dan een conclusie na deskundigenbericht nemen, waarna de rechter (weer) aan zet is. Deze hele procedure is op zichzelf al behoorlijk omslachtig en tijdrovend (partijen zijn zo een halfjaar tot een jaar verder), maar dat wordt nog moeizamer en tijdrovender wanneer partijen elkaar tegenwerken.

Met de deskundige wordt in de regel een termijn voor diens onderzoek afgesproken - doorgaans drie maanden - en deze wordt door de griffie ook wel bewaakt, maar een instrument om die termijn te (kunnen) handhaven is er feitelijk niet. Aalders heeft ervaren dat er deskundigen zijn die zonder enige vorm van gêne hun rapport pas anderhalf jaar later aan de rechter doen toekomen. Hoewel het de bedoeling van de wetgever was dat de kosten van een deskundigenbericht op dezelfde wijze worden begroot als de kosten van een getuigenverhoor, is de praktijk (inmiddels) dat de deskundige een marktconforme vergoeding ontvangt. Vooraf wordt weliswaar een voorschot met het oog op de dekking van de kosten gevraagd, maar het komt (zeer) geregeld voor dat een aanvullend voorschot nodig is (omdat het onderzoek meer tijd in beslag neemt dan was voorzien). In dat geval ontstaat een dilemma: partijen stemmen niet graag in met (nog) meer kosten, maar zonder de storting van een aanvullend voorschot zal de deskundige zijn onderzoek niet (kunnen) afronden, en daar is niemand bij gebaat. Dit leidt ertoe dat de kosten van het deskundigenbericht onvoorspelbaar zijn, waarbij tevens nog moet worden bedacht dat sommige deskundigen - zoals registeraccountants en medische deskundigen - een hoge vergoeding vragen. De rechter kan daar weinig tegen doen.

Maar in veel gevallen doen zich al complicaties voor bij de benoeming van een deskundige. Zo is lang niet altijd duidelijk wat voor soort deskundige moet worden ingeschakeld. Rechters (en ook advocaten) worstelen bijvoorbeeld al jaren met de vraag welk type deskundige moet worden benaderd bij zogenoemde post-whiplashklachten. En zodra duidelijk is welk type deskundige moet worden benoemd, is het vaak lastig om de juiste persoon te vinden. De rechter gaat zelf op zoek naar een deskundige als partijen het daarover niet eens kunnen worden. Daartoe kan hij eventueel gebruik maken van registers (databanken) van medische deskundigen, makelaars, accountants, bouwkundigen, enzovoort. Wordt echter een bijzondere deskundigheid verlangd, dan is het aanmerkelijk moeilijker om een deskundige te vinden. Aalders noemt een zaak die zij zelf heeft behandeld, waarin het ging om (een vermeend gebrek bij) de bouw van een replica van een VOCschip. In zulke gevallen blijkt het bijzonder ingewikkeld te zijn om iemand te vinden die over de verlangde deskundigheid beschikt en bovendien onpartijdig en onafhankelijk is.

En als de deskundige dan (eindelijk) zijn rapport heeft uitgebracht, is de prangende vraag: geeft het rapport een helder antwoord op de aan de deskundige voorgelegde vraag? Ook op dit punt zijn de ervaringen (onder rechters) wisselend, aldus Aalders. Het komt geregeld voor dat het rapport geen antwoord geeft op de gestelde vraag of blijkt dat - bij nader inzien - niet de juiste vraag is geformuleerd. Maar in alle gevallen gaat de discussie na de ontvangst van het deskundigenrapport onvermoeibaar voort. De teleurgestelde partij zal altijd bezwaar tegen het rapport maken. De Hoge Raad is de rechter evenwel enigszins tegemoetgekomen: in zijn arrest van 9 december 2011 overwoog hij namelijk dat de rechter, indien hij de zienswijze van de door hem aangewezen deskundige volgt, zijn beslissing in het algemeen niet verder hoeft te motiveren dan door aan te geven dat de door de deskundige gebezigde motivering hem overtuigend voorkomt. Hij dient overigens wel in te gaan op specifieke bezwaren van partijen tegen de zienswijze van de deskundige, voor zover deze bezwaren een gemotiveerde betwisting van de juistheid van die zienswijze inhouden. ${ }^{2}$

In de praktijk moeten kortom de nodige hindernissen worden genomen wanneer een deskundigenbericht wordt gelast. Wat Aalders betreft is het dan ook de vraag - zoals hiervoor al aangegeven - of de procedure van het deskundigenbericht wel altijd zo nuttig c.q. nodig is. $\mathrm{Zij}$ meent dat dit in veel gevallen niet zo is, en licht dat als volgt toe.

Het deskundigenbericht maakt deel uit van het wettelijke bewijsrecht. Evenals bij andere vormen van bewijslevering - zoals het getuigenbewijs - dienen aan het leveren van bewijs de beoordeling van de stellingen van partijen en de onderbouwing daarvan vooraf te gaan. Vaak zijn partijen door ervaring en hun bekendheid met de feiten goed in staat om de rechter adequaat over de relevante feiten te informeren. Volgens Aalders zou in het kader van de op hen rustende motiveringsplicht van partijen kunnen worden verlangd om hun stellingen (in voorkomende gevallen) met behulp van een eigen deskundigenbericht te onderbouwen. De wederpartij kan daar dan op reageren, al dan niet met een eigen deskundigenrapport. Dit rapport of deze rapporten kunnen dan de basis vormen voor het verdere processuele debat.

2. HR 9 december 2011, ECLI:NL:HR:2011:BT2921, NJ 2011/599 (X c.s./Stichting Flevoziekenhuis). 
Als er twee (partij)rapporten zijn, zouden de beide deskundigen op elkaars rapport kunnen reageren. En die reacties zouden zich dan niet moeten beperken tot het weerspreken van de visie van de ander. Uit de reacties over en weer zou moeten blijken op welke punten partijen het eens zijn en op welke punten zij het niet eens zijn, en waarom dat dan zo is. Aalders acht het zeer wel denkbaar dat de rechter op basis van die rapporten en het aldus gevoerde debat een goed beeld zal (kunnen) krijgen van de relevante feiten en de punten waarover nog moet worden beslist, waardoor de omslachtige route van het deskundigenbericht kan worden vermeden. Maar het is ook denkbaar dat het debat door deze werkwijze kan worden 'getrechterd' tot één vraag, die vervolgens ter beantwoording aan een derde deskundige - in wie beide partijen vertrouwen hebben - kan worden voorgelegd.

Om een goed en bruikbaar deskundigenrapport te krijgen is het cruciaal om aan de deskundige de juiste vraag/vragen te stellen. De ervaring leert dat dit niet altijd eenvoudig is. Het is niet voor niets dat de IWMD-werkgroep een standaardvragenlijst in letselschadezaken heeft opgesteld. Op zich is zo'n standaardvragenlijst nuttig, omdat daarmee wordt bewerkstelligd dat alle vragen aan de deskundige worden gesteld die nodig zijn om tot een beslissing te kunnen komen. Aalders heeft echter ondervonden dat de deskundige nogal eens 'de mist ingaat' bij de beantwoording van vragen, omdat hij de achtergrond ervan onvoldoende doorgrondt. Dan geeft de deskundige antwoorden die niet stroken met de rest van het rapport. Het is daarom aan te bevelen om - als rechter - de deskundige vooraf enig inzicht te geven in de wijze waarop van diens rapport gebruik zal worden gemaakt (bij de rechterlijke oordeelsvorming). Hiermee refereert Aalders aan haar derde stelling.

En wat is wijsheid als een rapport is uitgebracht dat vragen oproept? Welke mogelijkheden heeft de rechter in dat geval? Om (meer) duidelijkheid te krijgen zou een comparitie kunnen worden gelast, waarvoor ook de deskundige zou kunnen worden uitgenodigd. Volgens Aalders is het dan wel verstandig om het debat tijdens die comparitie te beperken tot éen of enkele kwesties of onduidelijkheden, zodat de discussie niet alle kanten op gaat. De rechter doet er goed aan bij de deskundige te verifiëren of hij diens antwoorden heeft begrepen.

Aalders' conclusie is dat het deskundigenbericht een tijdrovende en dure aangelegenheid vol obstakels is, waarvan de uitkomst lang niet altijd bruikbaar blijkt te zijn. Het verdient wat haar betreft dan ook aanbeveling dat de rechter eerst het partijdebat meer ruimte geeft en van partijen verlangt hun stellingen uitgebreider te onderbouwen, alvorens tot het gelasten van een deskundigenbericht over te gaan. Dit past naadloos in het nieuwe procesrecht en de uitgangspunten van KEI, waarin de nadruk is gelegd op de informatie- en bewijsaandraagplicht (en partijen worden aangemoedigd om hun geschillen zo veel mogelijk buiten de rechter om op te lossen).
Mocht na zo'n uitgebreider processueel debat blijken dat toch een deskundigenbericht nodig is, dan is de rechter - doordat hij beter is geïnformeerd - beter in staat om aan de deskundige de juiste vragen voor te leggen, zodat diens rapport meer toegespitst en daardoor beter bruikbaar zal zijn. Het heeft Aalders' voorkeur dat partijen gezamenlijk een deskundige zoeken (en vinden) die het beste past. Dit betekent dat advocaten hun natuurlijke neiging om elk voorstel van de wederpartij voor een te benoemen deskundige meteen af te wijzen, moeten onderdrukken (zie ook haar tweede stelling). Tot slot acht Aalders het wenselijk dat de deskundige enig inzicht heeft in het proces van oordeels- en besluitvorming door de rechter. Het is daarom aan te bevelen dat de rechter de deskundige vooraf informeert over de wijze waarop in de procedure van diens rapport gebruik zal worden gemaakt. Hierdoor zal de deskundige zich beter realiseren wat zijn rol is, hetgeen de kans vergroot dat hij een voor de rechter bruikbaar rapport zal uitbrengen.

\section{Discussie}

Mevrouw Franssen (advocaat) merkt op dat het haar verstandig lijkt om vóór de benoeming van een deskundige een regiezitting te gelasten. Dat vindt Aalders een goede suggestie.

De heer Ynzonides (advocaat) onderschrijft het nut van een partijdeskundigenrapport. Hij plaatst echter wel een kanttekening: zo'n rapport jaagt de partij in wier opdracht het wordt uitgebracht, behoorlijk op kosten. Wat Ynzonides betreft zou (ook) in een later stadium van de procedure - wanneer het processuele debat zich heeft ontwikkeld - aan partijen gelegenheid moeten worden geboden om eventueel nog een partijdeskundigenrapport te laten opstellen en in het geding te brengen. Verder zou er naar zijn mening meer tijd en ruimte moeten zijn voor een zitting met de partijdeskundigen erbij.

Aalders begrijpt dat een partij niet graag kosten wil maken voor een deskundigenrapport dat later door de wederpartij wordt 'afgeschoten' en/of voor de beoordeling van het geschil uiteindelijk niet bruikbaar blijkt te zijn.

De heer Van Niekerk (advocaat) merkt op dat advocaten in de praktijk nogal eens de neiging hebben om de deskundige die ze graag benoemd willen zien niet voor te dragen. Dit in verband met het risico dat deze voorgedragen deskundige door de wederpartij zonder pardon van de hand zal worden gewezen. Hij vraagt zich daarom af of de rechter rekening houdt met de onderbouwing die een partij geeft voor een door haar voorgedragen deskundige. In haar reactie geeft Aalders aan dat de deskundigheid voor een rechter vaak moeilijk te wegen is, waardoor ook de onderbouwing die voor een voorgedragen deskundige wordt gegeven, voor de rechter moeilijk op waarde te schatten is.

Volgens de heer Van Hezewijk (advocaat) is de praktijk vaak dat de rechter een deskundige benoemt indien de deskundigenrapporten die door partijen in het geding zijn gebracht, elkaar tegenspreken. Wat hem betreft zou het beter zijn om 
eerst tijdens een zitting een debat te voeren op basis van de voorliggende rapporten. Aalders is het van harte eens met deze suggestie.

\section{Stellingen:}

Inleiding prof. mr. J.A.M.A. Sluysmans ${ }^{3}$

1. In ons land is sprake van een wildgroei aan deskundigenregisters.

2. Geen van de bestaande deskundigenregisters bevat voldoende waarborgen voor de kwaliteit van de geregistreerde deskundigen.

3. Een geregistreerde deskundige zou ten minste eens in de vijf jaar op zijn of haar deskundigheid moeten worden geëxamineerd.

\section{Inleiding}

Sluysmans spreekt over de (bijzondere) rol van deskundigen in onteigeningszaken. Sluysmans refereert in dit verband allereerst aan het artikel 'De deskundige deskundige. Over registers en de "disclosure statement", in 2016 gepubliceerd in het tijdschrift Overheid en Aansprakelijkheid, waarin Van Ettekoven (voorzitter van de Afdeling bestuursrechtspraak van de Raad van State en hoogleraar aan de Universiteit van Amsterdam) pleit voor meer 'disclosure' door deskundigen over hun ervaring en achtergrond. ${ }^{4}$ Sluysmans merkt op dat hij actief is op het gebied van het onteigeningsrecht, niet alleen als hoogleraar, maar ook als advocaat en als door de rechtbank benoemde deskundige. Hij was ook lid van een internationale werkgroep, die - in 2015 - een zogenoemde 'Guide to Good Practices in Civil Judicial Expertise in the European Union' heeft opgesteld (onder auspiciën van het European Expertise and Expert Institute en het Civil Justice Programme van de Europese Unie).

In het onteigeningsrecht neemt de door de rechtbank benoemde deskundige een centrale positie in waar het gaat om het vaststellen van de schadeloosstelling in verband met een onteigening. Die positie is stevig in de wet verankerd (eerst in de wet van 1841 en thans in de wet van 1851). De rechter is verplicht om zich door een deskundige te laten adviseren. Doorgaans zijn dat drie deskundigen. De advisering door deskundigen is een vast onderdeel van de onteigeningsprocedure. De rechter heeft daarin dus geen keuzevrijheid (hetgeen bijzonder is).

In de beginjaren van het onteigeningsrecht was de taak van die deskundigen niet zo ingewikkeld. De schade door een onteigening behelsde vooral de 'werkelijke waarde' van hetgeen werd onteigend. De deskundigen hoefden dus niet veel meer te

3. Advocaat te Den Haag en bijzonder hoogleraar onteigeningsrecht aan de Radboud Universiteit Nijmegen. Zie ook zijn publicaties over de deskundige in het onteigeningsrecht: J.A.M.A. Sluysmans, 'De positie van de deskundigen in het onteigeningsrecht', TBR 2008, p. 25-30 en J.A.M.A. Sluysmans, 'Verleden en toekomst van de deskundige in het onteigeningsrecht', O\&A 2015/89.

4. B.J. van Ettekoven, 'De deskundige deskundige. Over registers en de "disclosure statement", O\&A2016/53. doen dan die waarde te begroten. $\mathrm{Zij}$ waren - in de woorden van Thorbecke (de geestelijke vader van ons huidige onteigeningsrecht) - een 'levend werktuig', een menselijke rekenmachine ten behoeve van de rechter dus. Daar kwam echter verandering in doordat de Hoge Raad in 1864 oordeelde dat het schadebegrip bij een onteigening veel ruimer is dan de wetgever (in 1851) voor ogen had gehad. De Hoge Raad ontwikkelde in zijn jurisprudentie - bij ontstentenis van wetgeving een kader van verfijnde schaderegels. Dit had tot gevolg dat van de deskundigen veel méér werd verwacht dan het enkel begroten van de marktwaarde van het onteigende. De deskundigen konden niet langer (naar behoren) functioneren zonder ook over juridische kennis te beschikken. De praktijk werd dat de voorzitter van het driemanschap van deskundigen een jurist was (doorgaans een advocaat), die de twee 'rekenaars' door het juridische moeras moest leiden en als penvoerder van de commissie optrad. In de loop van de twintigste eeuw zijn de rechtbanken in toenemende mate met vaste commissies van deskundigen gaan werken, waardoor tussen rechtbank en deskundige een vaste betrekking ontstond.

Twee separate ontwikkelingen in de naoorlogse periode hebben ertoe geleid dat het advies van de deskundigen aan de rechtbank een ongekend gewicht heeft gekregen. Dat was allereerst de professionalisering van het deskundigenschap: de deskundigen deden veel kennis en ervaring op en waren soms decennialang aan een rechtbank verbonden. Daar stond tegenover dat het rouleren van rechters tot gevolg had dat binnen de rechtbank relatief weinig expertise werd opgebouwd. De deskundigen zijn de constante factor in het proces, de rechter is slechts een passant. Door deze ontwikkelingen is een situatie ontstaan waarin de rechter zeer terughoudend is met het passeren van het deskundigenadvies en partijen terecht de indruk krijgen dat met het verschijnen van het advies de strijd in wezen al is gestreden. De deskundige heeft zich kortom in de loop der jaren ontwikkeld van 'rekenmachine' tot 'kwartiermaker' voor de rechter (ten behoeve van diens vonnis).

De dominante positie van de deskundigen in het onteigeningsrecht wordt in de wet niet erkend. De verklaring daarvoor is dat de wetgever in 1851 niet kon vermoeden dat die positie zo belangrijk zou worden. De (veranderde) werkelijkheid is dat de deskundigen een belangrijk stempel op het schadedebat zetten. In dat licht is het logisch dat partijen betrokken willen worden bij de benoeming van de deskundigen en waarborgen verlangen ten aanzien van hun deskundigheid. Waar de wetgever deze handschoen niet heeft opgepakt, heeft de rechterlijke macht dat onlangs wel gedaan. De expertgroep grondzaken - het informele overleg van de onteigeningsrechters in de rechtbanken - heeft na consultatie van 'stakeholders' een aantal afspraken gemaakt om de leemte in de (wettelijke) regelgeving omtrent deskundigen te vullen. Met betrekking tot de inspraak van partijen bij een benoeming is de afspraak gemaakt dat de rechtbank partijen (vooraf) in kennis zal stellen van een voorgenomen benoeming van een deskundige en 
aan hen gelegenheid zal bieden om gemotiveerd bezwaar tegen die benoeming te maken.

Ten aanzien van de borging van de kwaliteit en deskundigheid van de deskundige heeft de expertgroep het Landelijk Register Gerechtelijke Deskundigen (LRGD) gevraagd om tot de inrichting van een deskundigenregister te komen. Het register is in 2015 operationeel geworden. Slechts degenen die aan bepaalde eisen op het gebied van opleiding en ervaring voldoen, kunnen zich daarin laten inschrijven. En uitsluitend geregistreerde deskundigen komen voor een benoeming door de rechter in aanmerking. ${ }^{5}$ Naast het LRGD zijn er meer (landelijke) deskundigenregisters: het Nederlands Register Gerechtelijk Deskundigen (NRGD), de Stichting Deskundigen Onteigening en Bestuursrechtelijke Schadevergoeding (DOBS), de Deskundigenindex van de Rechtspraak (DIX) en de Nederlandse Vereniging voor Medisch Specialistische Rapportage (NVMSR). Van Ettekoven heeft, in zijn artikel in Overheid en Aansprakelijkheid, opgemerkt dat sommige van deze registers nauwelijks zelfstandig bestaansrecht hebben. Sluysmans is het daar van harte mee eens.

Genoemde registers hebben gemeen dat zij - voor zover het de borging van de kwaliteit van de geregistreerde deskundigen betreft - werken met een systeem van toegang en toegelaten blijven. Toegang verkrijgen deskundigen in de regel door een combinatie van het succesvol voltooien van een opleiding en relevante ervaring. Toelating blijft behouden via het jaarlijks vergaren van voldoende punten in het kader van permanente educatie (PE). Sluysmans is van mening dat een dergelijk systeem van toegang en toegelaten blijven niet volstaat om de kwaliteit van de geregistreerde deskundigen daadwerkelijk (blijvend) te borgen. Dat heeft te maken met het feit dat in het kader van de permanente educatie onvoldoende strenge eisen worden gesteld aan het behalen van PE-punten en bovendien de controle op behaalde PE-punten tekortschiet. Sluysmans onderschrijft de stelling van Van Ettekoven dat de registers geen 'wondermiddelen' zijn die bij voorbaat elke discussie over de deskundigheid van de deskundige uitsluiten. Het enkele feit dat de deskundige is ingeschreven in een deskundigenregister betekent niet dat over zijn kwaliteit geen gerede twijfel kan bestaan. Sluysmans acht de thans aan de orde zijnde marginale (en minimale) borging van deskundigheid - zeker waar het gaat om door de rechter te benoemen deskundigen - niet aanvaardbaar. Het staat ook op gespannen voet met de hiervoor al genoemde 'Guide', waarin wordt gepleit voor een 'quality assurance system', dat als essentieel onderdeel bevat 'a permanent system of checks and assessments of quality'.

Als 'good practice' wordt - vrij vertaald - beschouwd het functioneren van een systeem van permanente kwaliteitscontrole. Dat is volgens Sluysmans bij geen van de genoemde landelijke registers aan de orde. Er is zijns inziens niet alleen een gebrek aan permanente controle, ook ontbreekt na toelating

5. Zie over het LRGD o.m. Sluysmans 2015 en Van Ettekoven 2016/53. Zie ook www.lrgd.nl. eenvoudigweg elke controle op de kwaliteit van de deskundige. Hier ligt wat Sluysmans betreft een 'terra incognita', die in de nabije toekomst nadere verkenning behoeft. Zeker in een dynamische samenleving als de onze - waarin nieuwe ontwikkelingen elkaar in rap tempo opvolgen - valt niet vol te houden dat deskundigheid een statische kwaliteit is. Deskundigheid dient keer op keer opnieuw te worden aangetoond. Naar zijn mening kan dit alleen op een geschikte wijze gebeuren door deskundigen periodiek (eens in de drie of vijf jaar) aan een toets c.q. examen te onderwerpen. Dat is voor de ingeschreven deskundige wellicht ongemakkelijk en confronterend, maar het biedt ook een kans om de ruimte voor discussie over zijn deskundigheid te minimaliseren.

\section{Discussie}

De heer Wiersma (voormalig onderzoeker aan de UvA) vraagt of er voldoende mankracht is om examens bij deskundigen af te nemen. Volgens Sluysmans is dat in ieder geval te regelen voor zover het de toetsing van deskundigen op het gebied van het onteigeningsrecht betreft.

De heer De Groot (raadsheer in de Hoge Raad) wijst op de NVMSR, ontstaan uit onvrede over de kwaliteit van medisch specialistische rapportages, met name op het gebied van het letselschaderecht. De NVMSR heeft eerst een richtlijn voor het maken van een medisch specialistisch rapport ontwikkeld en vervolgens een opleiding opgezet voor mensen die als medisch deskundige willen rapporteren. $\mathrm{Na}$ het met goed gevolg afleggen van het examen in het kader van deze opleiding kan men zich in het register laten inschrijven. De ingeschreven deskundigen moeten aan de gestelde eisen ten aanzien van permanente educatie voldoen. Er is ook een klachtenregeling ingericht voor mensen die niet tevreden zijn over een uitgebracht rapport. De Groot vraagt zich af of andere registers hiervan kunnen leren.

Sluysmans merkt op dat ook het LRGD een klachtenregeling kent. Waar het hem vooral om gaat, is dat er meer moet gebeuren op het gebied van permanente educatie. Hij vindt het de verantwoordelijkheid van het register om de ingeschreven deskundigen periodiek te examineren teneinde vast te stellen of hun deskundigheid up-to-date is. Sluysmans vindt het medisch register en ook het LRGD een behoorlijke basis, maar wat hem betreft mag de lat nog hoger worden gelegd. In bijvoorbeeld het Angelsaksische systeem worden strengere eisen aan geregistreerde deskundigen gesteld. Dat zou tot voorbeeld kunnen strekken.

Van Hezewijk vraagt zich af of het niet beter zou zijn om de deskundige met het oog op zijn benoeming 'ad hoc' op kwaliteit te toetsen. Volgens Sluysmans is dat mede afhankelijk van de gekozen invalshoek. Zo is de borging in het Angelsaksische systeem anders geregeld, onder meer door een veel uitgebreidere 'disclosure' bij de benoeming. Het gaat hem erom dat de kwaliteit wordt geborgd. Het enkele feit dat iemand al twintig jaar actief is als deskundige betekent niet zonder meer dat daarmee de kwaliteit van de deskundige is geborgd. 
Stellingen:

\section{Inleiding mr. drs. D.A. Verburg ${ }^{6}$}

1. In de expertocratie die de elite promoot, spelen deskundigen een steeds grotere rol; in het populisme (alternative facts) delven deskundigen het onderspit. De deskundige moet zich verantwoorden om overeind te blijven. Hij/zij moet een verhaal hebben.

2. De deskundige die is ingehuurd door het bestuursorgaan moet gewoon zijn/haar vak uitoefenen en hij/zij moet dat ook laten zien. Neutraliteit is de basis.

3. De deskundige moet meer oog hebben voor het proces waarmee aan de waarheidsvinding gestalte wordt gegeven en moet niet alleen letten op de feiten. We hebben de feiten en we hebben het verhaal over de feiten, en dat verhaal is essentieel. Hoe is de deskundige tot dat verhaal gekomen en wie mochten er allemaal meepraten voordat dat deskundigenrapport tot stand kwam?

4. In de huidige samenleving gaat het proces van deskundigeninbreng vóór de 'feiten', want tja, wat zijn die 'feiten'?

\section{Inleiding}

De inleiding van Verburg ziet op de rol van de deskundige in de bestuursrechtelijke procedure. Verburg bespreekt aan de hand van vier arresten van het Europees Hof voor de Rechten van de Mens (EHRM) wanneer de bestuursrechter zijn oordeel mag baseren op deskundigeninbreng van een van de partijen, het bestuursorgaan. Zijn voordracht biedt ook inkijkjes die voor civilisten van belang kunnen zijn. Dat geldt zeker voor het onderwerp 'het gezag van de deskundige'. Vanuit het bestuursrechtelijke en het civielrechtelijke perspectief zal hij spreken over de neutraliteit van een partijdeskundige: moet die deskundige niet gewoon zijn werk doen?

De stellingen hebben als gemeenschappelijke noemer dat het gezag van de deskundige niet meer vanzelf spreekt. De witte jas van de arts is net zomin als de microscoop van de bioloog een garantie voor de waarheid. Veel meer dan alleen de kennis van de deskundige zijn in de afgelopen decennia het verhaal van de deskundige en de mate waarin hij of zij betrokken is bij de totstandkoming van dat verhaal op de voorgrond komen te staan. Verburg wijst op een interview met Nichols, hoogleraar veiligheidsvraagstukken aan het Naval War College op Rhode Island en schrijver van het boek met de veelzeggende titel The death of expertise, ${ }^{7}$ in NRC Handelsblad van 13 juni 2017 met de titel 'VS dwepen met eigen onwetendheid'. Het artikel is een aaneenrijging van de feitenresistentie van de Amerikaanse samenleving, die ook ons te wachten staat. $\mathrm{Nu}$ al zien we ook in Europa een afkalving van het geloof in de wetenschap.

De ontwikkeling die hieraan ten grondslag ligt, is goed beschreven in Gezagsdragers onder redactie van vooral Van

6. Senior rechter en inhoudelijk adviseur Rechtbank Midden-Nederland en bestuurslid NVvP.

7. T.M. Nichols, The death of expertise: The campaign against established knowledge and why it matters, New York: Oxford University Press 2017. den Brink. ${ }^{8}$ Eind jaren zestig was institutioneel gezag dominant. Het individuele gezag was daarvan een afgeleide. Er was ontzag voor De Politie, De Rechtspraak, De Regering en De Wetenschap. Onder invloed van opleiding, internet, mobiliteit en vooral individualisering is persoonlijk gezag meer en meer op de voorgrond komen te staan. Deze instituties hebben nog steeds veel gezag, maar de opvatting over institutioneel gezag is alleen a priori, voordat men in contact komt met de gezagsdragers. In een tijd van hogere opleiding, toegang tot informatie via internet, grotere mobiliteit en vooral een hogere mate van individualisering gaat het persoonlijk gezag een veel grotere rol spelen. De burger vraagt zich af: Gaat deze gezagsdrager een relatie met mij aan? Erkent hij of zij mij als waardevolle burger van deze samenleving? Als deze individuele gezagsdrager het goed doet, straalt dat positief af op de institutie. De situatie is dus bijna omgekeerd: van institutioneel gezag van de wetenschap en persoonlijk gezag van de wetenschapper als afgeleide daarvan (tot de jaren zestig) naar een toestand waarin het persoonlijk gezag van de wetenschapper veel meer op de voorgrond komt en het institutionele gezag als afgeleide daarvan geldt $(\mathrm{nu})$.

Het gezag van de wetenschap is niet meer automatisch, ook als het gaat over rechtspraak op basis van deskundigeninbreng. 'Dit is het antwoord van de wetenschap' volstaat niet voor de deskundige. Hij of zij zal een relatie moeten aangaan met degene om wie het gaat. De rechter die het oordeel baseert op een deskundigenoordeel, moet nagaan of die relatie is aangegaan.

De afgelopen jaren heeft het EHRM vele uitspraken gedaan over deskundigeninbreng van de zijde van het bestuursorgaan, die aan het oordeel van de rechter ten grondslag is gelegd. Verburg zal daarvan vier arresten bespreken: Korošec/Slovenië van 8 oktober 2015,9 Spycher/Zwitserland van 17 november $2015,{ }^{10}$ Letinćić/Kroatië van 3 mei $2016^{11}$ en Krunoslava Zovko/Kroatië van 23 mei $2017 .{ }^{12}$ Met name over de beslissing in de zaak Korošec is binnen bestuursrechtelijk Nederland ophef ontstaan. Uit dit arrest is afgeleid dat de nationale rechter van het EHRM altijd een eigen deskundige moet benoemen, en dat het EHRM zou hebben geoordeeld dat de burger het deskundigenadvies van het bestuursorgaan niet eerlijk heeft kunnen weerspreken omdát de nationale rechters weigerden een eigen deskundige te benoemen. ${ }^{13}$ Verburg denkt

8. Th. Jansen, G. van den Brink \& R. Kneyber (red.), Gezagsdragers. De publieke zaak op zoek naar haar verdedigers, Amsterdam: Boom 2012.

9. EHRM 8 oktober 2015, ECLI:CE:ECHR:2015:1008JUD007721212, RSV 2016/27, m.nt. W.A. Faas.

10. EHRM 17 november 2015, ECLI:CE:ECHR:2015:1117DEC $002627512, R S V 2016 / 28$, m.nt. F.A. Faas.

11. EHRM 3 mei 2016, ECLI:CE:ECHR:2016:0503JUD000718311, RSV 2016/160, m.nt. F.A. Faas.

12. EHRM 23 mei 2017, ECLI:CE:ECHR:2017:0523JUD005693513, NJB $2017 / 1858$.

13. Zo ook B.J. van Ettekoven, 'De betekenis van de uitspraak Korošec tegen Slovenië voor het Nederlandse bestuursrecht', $O \& A 2016 / 29$, punt 2, en T. Barkhuysen \& M.L. van Emmerik in hun noot onder $A B$ 2016/167, punt 2 . 
echter dat de bestuursrechtspraak in Nederland veel meer te maken zal gaan krijgen met de gevolgen van de zaak Letinčić.

Verburg heeft de consequenties van deze jurisprudentie voor de Nederlandse bestuursrechtspraak stapsgewijs geanalyseerd.

De eerste vraag die volgens hem dient te worden beantwoord, is hoe art. 6 van het Europees Verdrag ter bescherming van de rechten van de mens en de fundamentele vrijheden (EVRM) in het spel komt. In deze bepaling wordt een fair trial voor een onafhankelijke en onpartijdige rechter gegarandeerd, met hoor en wederhoor, met gelijkheid der wapenen, met uiteindelijk een controleerbaar en aanvaardbaar gemotiveerde beslissing én - en daar gaat het Verburg nu om - de bevoegdheid om te oordelen over alle kwesties van feiten en recht, zogenoemde full jurisdiction.

Art. 6 EVRM geldt als zodanig niet voor bestuursorganen, voor deskundigen die zijn benoemd door de rechter en voor deskundigen die advies uitbrengen aan partijen. Het is dus vreemd dat het EHRM überhaupt kan beslissen dat een zaak niet voldoet aan de eisen van art. 6 EVRM vanwege bijvoorbeeld de manier waarop een deskundige van het bestuursorgaan te werk is gegaan. Het EHRM lijkt hiermee te worstelen.

Als een rechter moet leunen op deskundigeninbreng bestaat er een spanningsveld. De rechter moet garanderen dat ten overstaan van hem kan worden geprocedeerd over alle feiten, maar voor zover hij daarbij leunt op deskundigeninbreng moet hij al snel zeggen: 'Daar weet ik niets van.' Om deze reden heeft het EHRM de afgelopen decennia consequent beslist dat ook de procedure bij de gerechtelijke deskundige moet voldoen aan de eisen van art. 6 EVRM, vooral aan de eis van hoor en wederhoor. ${ }^{14}$ Dit geldt met name als de vraag die de gerechtelijke deskundige moet beantwoorden nagenoeg gelijk is aan de vraag die de rechter moet beantwoorden. In overweging 60 van de zaak Letinčić worstelt het EHRM hiermee. Het durft net niet te zeggen dat de eisen uit de zaak Mantovanelli ook gelden voor de deskundige van het bestuursorgaan als de rechter zijn oordeel wil baseren op dat van de door het bestuursorgaan ingeschakelde deskundige. Als de rechter een deel van zijn rechtsbeschermingskwaliteiten als het ware moet uitlenen aan de deskundige, schiet die rechter tekort als hij gebreken in die deskundigenprocedure niet heelt in de rechterlijke procedure.

Vervolgens is het de vraag wanneer de procedure bij de deskundige van het bestuursorgaan uiteindelijk een fair trialgebrek bij de rechter kan opleveren. Twee aspecten zijn daarbij van belang.

In de eerste plaats moet de ingeschakelde deskundige niet alleen deskundig zijn, maar ook neutraal. Hij dient zijn vak naar de regelen der kunst uit te voeren, ook al werkt hij in opdracht van het bestuursorgaan. Als kan worden getwijfeld aan de neutraliteit van de door het bestuursorgaan ingeschakelde deskundige én de rechter toch zijn oordeel op dat des-

14. EHRM 18 maart 1997, ECLI:NL:XX:1997:AD4449, NJ 1998/278, m.nt. H.J. Snijders (Mantovanelli/Frankrijk). kundigenstandpunt wil baseren, moet worden beoordeeld of de burger wel een gelijkwaardige rol heeft bij de totstandkoming van het oordeel van de rechter. Dit element van de neutraliteit van de deskundige wordt in de regel uitgewerkt aan de hand van de volgende criteria uit het arrest Sara Lind Eggertsdóttir/IJsland van 5 juli 2007: $:^{15}$

1. de aard van de aan de deskundige opgedragen taak;

2. de hiërarchische verhouding van de deskundige tot het betrokken bestuursorgaan; en

3. de rol van de deskundige in de procedure, in het bijzonder het gewicht dat de rechter aan het deskundigenoordeel toekent.

Bij de aard van de taak is van belang wat van de deskundige wordt gevraagd, of de vraagstelling ruim of smal is, en hoe de beantwoording is ingekaderd, bijvoorbeeld door regelingen en aanwijzingen van het bestuursorgaan, zoals de Regeling rijgeschiktheid in CBR-zaken.

Bij de positie van de deskundige ten opzichte van het bestuursorgaan wordt erop gelet of de deskundige in dienst is van het bestuursorgaan, of de deskundige grotendeels van het bestuursorgaan afhankelijk is voor zijn inkomen, of de deskundige veel andere inkomsten heeft, en of er institutionele waarborgen zijn voor zijn neutraliteit, bijvoorbeeld ontslagbescherming of een lange benoemingsduur.

Bij de rol van de deskundige in de procedure is relevant of de deskundige een feitenoordeel geeft, waarna het bestuursorgaan zelfstandig een besluit neemt, of in feite het uiteindelijke besluit dicteert.

Deze drie criteria worden in onderling verband en samenhang beschouwd. Dat een deskundige in dienst is van het bestuursorgaan betekent in ieder geval niet dat hij niet neutraal kan zijn. Het EHRM neemt dus niet zo snel aan dat een partijdeskundige een partijdige deskundige is.

In de tweede plaats heeft de rechter zich af te vragen hoe de betrokkenheid van de burger bij de deskundigenprocedure of de procedure bij het bestuursorgaan is geregeld. Hier is het kernwoord effectieve tegenspraak, zoals volgt uit de zaak Letinčić:

'It follows that the Administrative Court, acting in the last instance of the administrative proceedings as a judicial body that had full jurisdiction to examine all factual and legal questions arising in the context of the case, failed to critically approach and remedy the procedural shortcomings related to the applicant's exclusion from the process of commissioning and obtaining of the expert report (...).'

De nationale rechter handelt niet steeds verkeerd als hij zich baseert op het deskundigenadvies dat is uitgebracht aan het bestuursorgaan. Het EHRM acht in de zak Spycher het feit dat de deskundigen in opdracht van het bestuursorgaan werken, niet doorslaggevend. Het betreffende medisch centrum

15. EHRM 5 juli 2007, ECLI:NL:XX:2007:BB5086, NJ 2010/323, m.nt E.A. Alkema. 
was geen afdeling van de federale overheid en had verschillende klanten. De neutraliteit is dus geen probleem. In deze zaak is van belang dat Spycher in de bestuurlijke voorfase wel degelijk de kans kreeg om tegenspraak te leveren. $\mathrm{Zij}$ heeft echter volstaan met het maken van bezwaar tegen de keuze voor de deskundigen en deze grond niet verder onderbouwd dan door te wijzen op de contractuele relatie tussen de overheid en het medisch centrum. Spycher had in de bestuurlijke voorfase gelegenheid commentaar te leveren op de deskundigeninbreng, maar heeft deze kans laten lopen. Pas bij de rechter komt zij met het aanbod twee behandelend artsen te laten horen. De nationale rechter kon dit bewijsaanbod passeren. Er was geen gebrek dat in de gerechtelijke fase hersteld moest worden.

Ten slotte is aan de orde wat de rechter moet doen als hij constateert dat er in de procedure bij het bestuursorgaan iets niet in orde is. Als de neutraliteit van de deskundige of de mate waarin iemand wordt betrokken in de totstandkoming van het deskundigenrapport niet aan de vereisten voldoet, moet de rechter deze tekortkoming repareren. Het EHRM beziet immers de procedure 'as a whole': gebreken in de ene fase kunnen worden hersteld in de volgende. Over de manier waarop de rechter een tekortkoming moet repareren, laat het EHRM zich niet uit. Dat is aan de nationale rechter. Deze moet voldoende tegenspraak organiseren, bijvoorbeeld door het horen van de deskundige als getuige, het stellen van schriftelijke vragen aan die deskundige of het benoemen van een eigen deskundige.

Verburg concludeert dat de noodzaak de burger bij de totstandkoming van het deskundigenbericht te betrekken veel van de procedure bij de deskundige vergt en dat de bestuursrechter op dat vlak vaker tot reparatie zal moeten overgaan.

\section{Discussie}

De heer Tonino (jurist) vraagt zich in het licht van de voordrachten van de heren Sluysmans en Verburg af of een gebrek aan deskundigheid van de deskundige niet problematisch is in het licht van art. 6 EVRM.

Verburg verduidelijkt dat het dan, wat het bestuursrecht betreft, gaat om de situatie dat de rechter moet beoordelen of het deskundigenadvies dat het bestuursorgaan heeft ingewonnen, kan worden gevolgd. In het geval van het ongeldig verklaarde rijbewijs kan de rechter te maken krijgen met het volgende probleem. Alle plusminus twintig psychiaters die ervaring hebben met het bijzondere, niet uitsluitend medische begrip 'alcoholmisbruik in ruime zin', werken voor het CBR. De rechter kan daarom een van deze psychiaters niet als eigen deskundige benoemen, terwijl andere psychiaters de vereiste specifieke deskundigheid missen. In zo'n geval is het voor de rechter moeilijk zelf deskundigenadvies in te winnen. De rechter kan wel beoordelen of het rapport consistent en volledig is, en of er een logische lijn in zit. De toets van de rechter is dus inderdaad problematisch.
Sluysmans merkt op dat bij schadezaken in het bestuursrecht de Stichting Adviesbureau Onroerende Zaken (SAOZ) vaak door het bestuursorgaan wordt ingeschakeld om planschade of nadeelcompensatie vast te stellen. De competentie van de deskundige van de SAOZ wordt in rechte wel aangevochten. De lijn van de Afdeling bestuursrechtspraak van de Raad van State is dat de SAOZ te goeder naam en faam bekendstaat en de deskundigen die er werken daarom voldoende deskundig zijn. Dat gaat ver. Ook de Stichting Advisering Bestuursrechtspraak (StAB) wordt door bestuursrechters als deskundige ingeschakeld, vooral op het gebied van het omgevingsrecht. Kritiek op de expertise van een deskundige van de StAB wordt in de rechtspraak op dezelfde wijze beoordeeld. Bedacht moet echter worden dat niet iedereen binnen een gezaghebbend instituut over dezelfde deskundigheid beschikt.

De heer Maathuis (advocaat) vraagt aan welke partij het is om de objectieve feiten te stellen die een suspicion van partijdigheid, zoals in de zaak Korošec, onderbouwen of ontkrachten.

Volgens Verburg blijkt uit de zaak Spycher duidelijk dat het de burger is die concrete aanknopingspunten moet aanleveren waarom in het concrete geval geen sprake is van onpartijdigheid.

De heer Kastein (advocaat) constateert dat vandaag is gezegd dat de deskundige zijn gezag moet verdienen door zijn verhaal te vertellen en dat dit wellicht vreemd overkomt op juristen. Dat laatste valt volgens Kastein wel mee. Een advocaat moet vaak zijn cliënt, die doorgaans zelf aan de hand van Google al een diagnose heeft gesteld van het probleem, overtuigen van de juistheid van zijn meer formele visie op de zaak. Op cursussen wordt advocaten sinds een paar jaar bovendien geleerd de zaak niet te droog te presenteren, maar meer een verhaal te vertellen.

Verburg merkt op dat advocaten ook gezagsdragers zijn en dat zij inderdaad met dezelfde problemen worden geconfronteerd. Dat had hij zich niet direct gerealiseerd toen hij zei dat het misschien vreemd over zou komen. De advocaat zit in hetzelfde schuitje als die deskundigen.

Wiersma vraagt zich af of het voorkomt dat in bestuursrechtelijke zaken de burger zelf een deskundigenbericht inbrengt.

Dat is afhankelijk van het type zaak, aldus Verburg. In het omgevingsrecht komen burgers vaak met een eigen deskundige, zeker als het gaat om grotere plannen. In mededingings- en telecomzaken is het vaak een battle of experts. In het meer sociale domein, de uitkeringen- en voorzieningensfeer, zie je aan de zijde van de burger eigenlijk nooit een eigen deskundige. Burgers dragen daar wel informatie aan afkomstig van hun eigen behandelaars. Dit is geen contra-expertise, zoals normaal gesproken wordt verlangd. Van hen valt echter niet te vergen dat zij een eigen deskundige betalen. Uit een oogpunt van ongelijkheidscompensatie wordt de informatie uit de behandelende sector daarom aanvaard. De deskundige van het bestuursorgaan moet deze informatie vervolgens in zijn 
bespreking betrekken. Zo wordt getracht de burger in zijn zwakkere positie te beschermen.

Wiersma leidt uit de bespreking van de zaak Korošec af dat de rechter zelf moet beoordelen of het deskundigenrapport juist is. In het civiele recht zou de rechter dan de simpele redenering kunnen volgen dat aan het deskundigenrapport feiten ten grondslag liggen die niet zijn weersproken en daarom vaststaan.

Verburg werpt op dat art. 149 en $150 \mathrm{Rv}$ niet gelden in het bestuursrecht. De bestuursrechter vult ambtshalve de rechtsgronden aan, net zoals in art. $25 \mathrm{Rv}$ staat. Maar hij kan bovendien ambtshalve de feiten aanvullen. Weer uit een oogpunt van ongelijkheidscompensatie is niet wenselijk geacht dat de burger de zaak verliest als hij vergeet iets te weerspreken. De bestuursrechter mag zelf niet-gestelde feiten uit het dossier tot onderwerp van debat maken, zolang deze feiten maar ter zake dienend zijn in het licht van de beroepsgronden.

De heer Goethals (advocaat) heeft begrepen dat in de rechtspraak wel wordt aangenomen dat een deskundige die in dienst is van een zelfstandig bestuursorgaan toch niet partijdig is omdat zijn rapport er goed uitziet. Goethals vraagt zich af hoe dan onafhankelijkheid kan worden getoetst. Partijdigheid uit zich toch in het rapport of de totstandkoming ervan, dus in de wijze waarop de deskundige zich gedraagt?

Verburg denkt dat een parallel getrokken kan worden met de Hauschildt-criteria voor een onpartijdige rechter. ${ }^{16} \mathrm{Het}$ EHRM kijkt naar de institutionele inbedding om vast te stellen of aan het vereiste van onpartijdigheid is voldaan. In dat licht is bijvoorbeeld van belang of de deskundige werkzaam is op een bureau dat op afstand is geplaatst van het bestuursorgaan, en of de deskundige voor langere tijd is benoemd. De vraag doelt meer op de subjectieve vorm van de expertise. Dan is bijvoorbeeld van belang of de woordkeuze van het rapport erop hint dat de deskundige zijn oren heeft laten hangen naar het bestuursorgaan.

De heer Hofhuis (oud-rechter) werpt de vraag op hoe actief de rechter mag zijn bij het benoemen van een deskundige en tijdens het onderzoek door de deskundige. In dat verband heeft hij twee vragen. Mag de rechter zich bemoeien met de keuze voor een deskundige, en hoe indringend moet hij de deskundigheid en onafhankelijkheid onderzoeken? Hoe kan worden gewaarborgd dat een deskundige bij onenigheid tijdens zijn onderzoek de rechter kan raadplegen, en welke procedure geldt in dat geval voor het optreden van de rechter?

Volgens Aalders kan de rechter zo actief zijn als hij of zij wil, zolang maar transparantie naar partijen wordt betracht. Een deskundige wordt over het algemeen door een juridisch medewerker aangezocht om te voorkomen dat de deskundige met de rechter dingen bespreekt waar partijen niet van weten en waarover zij zich niet hebben kunnen uitlaten. Zolang een rechter open is naar partijen over wat hij met de deskundige bespreekt en welke instructies hij aan de deskundige geeft, denkt Aalders dat alles met de deskundige bespreekbaar is. Zij heeft juist gepleit voor een uitgebreidere instructie aan de deskundige dan thans gebruikelijk is. Dat kan in de uitspraak, maar ook telefonisch, mits het besprokene met partijen wordt gedeeld. Tijdens het onderzoek door de deskundige vinden contacten plaats tussen partijen en de deskundige waar de rechter geen zicht op heeft. Een deskundige wordt zo geïnstrueerd dat hij bij conflicten de rechter kan raadplegen. In dat geval moet de rechter de regie terugnemen en bijvoorbeeld voor de deskundige beslissen dat hij bepaalde vragen niet hoeft te beantwoorden.

Opgeworpen wordt dat de burger geen inspraak heeft in de keuze van het bestuursorgaan voor een deskundige. Uit de zaak Sara Lind Eggertsdóttir/IJsland volgt dat een gebrek bij de deskundige later in rechte kan worden gerepareerd. Ligt er niet een taak voor het bestuursorgaan om het verhaal van de burger al in het eerdere stadium beter te waarborgen? Is dat niet logischer dan het later aan de rechter over te laten?

Verburg merkt op dat er jaarlijks 2,5 miljoen bezwaarschriften worden ingediend. Met deze aantallen is het voor bestuursorganen volgens hem niet mogelijk steeds zulk onderzoek te doen. 